\title{
Ergenlerin Çocuk Sevme Düzeyleri ve Öfke İfade Tarzlarının Bazı Değişkenlere Göre İncelenmesi
}

\section{Examination of the Levels of Adolescent of Child Like and the Expression of the Anger According to Some Variables}

Öğr. Gör. Gül Kadan¹, Çankırı Karatekin Üniversitesi Sağlık Bilimleri Fakültesi Çocuk Gelişimi Bölümü, gulkadan@gmail.com

Öğr. Gör. Besime Bilmez, Bingöl Üniversitesi Genç Meslek Yüksekokulu Çocuk Bakımı ve Gençlik Hizmetleri, meral bilmez@hotmail.com

\section{$\ddot{O} z$}

Eğitim sisteminde çocukla çalş̧an bireylerin çocuklara yaklaşım tarzları ve çocukları sevme düzeyleri, oldukça önemlidir. Çünkü çocuklara yaklaşım ve çocuk sevme hedeflere kolayca ulaşılmasının bir aracı olarak düşünülebilir. Aynı zamanda çocuklar eğitim sürecinde yetişkinleri ve kendisiyle iletişim ve etkileşim içinde olan bireyleri rolmodel olarak almaktadırlar. Dolayısıyla rol-model olarak alınan kişilerin davranışları ve öfkeden uzak olmaları da hayati önem taşımaktadır. Bu noktadan hareketle araştırmada, Kız Meslek Lisesi Çocuk Gelişimi Bölümü öğrencilerinin bazı sosyodemografik değişkenlere göre sürekli öfke-öfke ifade tarzı ile çocuk sevme düzeyleri arasında anlamlı farklılık olup olmadığını belirlemek, sürekli öfke-öfke ifade tarzı ile çocuk sevme düzeyleri arasındaki ilişkiyi saptamak amaçlanmıştır. Tarama modelinde gerçekleştirilen araştırmada Bingöl İl Milli Eğitim Müdürlüğü’ne bağh olan Kız Meslek Lisesi Çocuk Gelişimi Bölümü öğrencileri ile çalısılmıştır. Araştırmada "Genel Bilgi Formu", "Sürekli Öfke- Öfke İfade Tarzı Ölçeğı” ve "Barnett Çocuk Sevme Ölçeğı" kullanılmıştır. Araştırma sonucunda katıllımcıların \%54,6'sının 16 yaş ve üzerinde, \%42'sinin dördüncü sınıfta, \%51,2'sinin üç ve daha fazla kardeşe sahip, \%34,5'inin ilk çocuk olduğu, \%41,3'ünün annesinin \%47,1'inin babasını okuryazar-ilkokul mezunu olduğu belirlenmiştir. Öğrencilerin \%66,6's1 üniversiteye gitmek isterken, \%75,1’i iletişim dersi almamıştır. Araşıırma sonucunda, sınıf düzeyi arttıkça öğrencilerin öfkelerini daha iyi kontrol ettikleri, kardeş sayısı arttıkça öfke düzeyinin arttı̆̆ı, iki kardeşi olan çocukların öfkelerini daha iyi kontrol edebildiği, annenin eğitim düzeyi yükseldikçe öğrencilerin öfkelerini daha iyi kontrol ettikleri, üniversiteye gitmek istemeyen öğrencilerin daha fazla öfkeli oldukları, öfke kontrolü ve çocuk sevme arasında pozitif yönde anlamlı bir ilişkinin olduğu sonucuna ulaşılmıştır. Araştırma sonuçlarına dayanarak öğrencilere öfke kontrolüne yönelik eğitimler düzenlenmesi, aile içinde kardeşler arasındaki dayanışma ve hoşgörüyü artırmak için destekleyici eğitim programlarının uygulanması önerilebilir.

Anahtar Kelimeler: Öfke, öfke kontrolü, çocuk sevme, ergenlik, öğretmen, yardımcı personel

\footnotetext{
1 Sorumlu Yazar
} 


\begin{abstract}
The way in which the children working with children in the education system approaches children and loves children is very important. Because children approach and children love can be considered as a means of achieving the goals. All the same time, the children take the role of adults and the individuals who communicate and interact with themselves as role models in the educational process. Therefore the behavior of the people who are taken as role models and their being away from the anger are also vital. From this point of view, it was aimed to determine whether there is a significant difference between the level of continuous anger-anger expression and the level of child love according to some sociodemographic variables, and to determine the relationship between continuous anger-anger expression styles and child love levels in the Vocational High School Child Development. Department students. In the research carried out in the screening model, the Department of child development of girls Vocational High School affiliated to the Bingöl Provincial Directorate of National Education worked with the students. "General Information Form", “Continuous Anger- Anger Expression Style Scale” and "Barnett Child Love Scale" were used in the research. As a result of the study 54,6\% of the participants were aged 16 and over, $42 \%$ of them were in the fourth grade, $51,2 \%$ had three or more siblings, $34,5 \%$ were the first children $41,3 \%$ her mother's literacy and primary school graduation and $47,1 \%$ her father's literacy and primary school graduation. $66,6 \%$ of the students were going to university, 75,1\% did not take communication courses. As a result of the research, it was found out that as the level of the class increased, the students control the anger more, the anger level increased as the number of siblings increased, the children with two siblings could control the anger more the students, anger-control and child loving were found to have a meaningful relationship in the positive direction. Based on the results of the research, it can be suggested to organize the trainings for the anger control for the students, to implement the supportive education programs to increase tolerance and solidarity among the brothers in the family.
\end{abstract}

Keywords: Anger, anger control, child love, adolescence, teacher, auxiliaries

\title{
Giriş
}

Toplumda kişilerin birlikte yaşayabilmelerinde birbirlerine karşı tutum ve yaklaşımları oldukça önem taşımaktadır. Özellikle söz konusu olan çocuklar olduğunda etrafında iletişim ve etkileşim içinde oldukları bireylerin ve yetişkinlerin davranış ve tutumları oldukça önemlidir. Bu önem çocukların öğrenme sürecinde yetişkinlerin davranışlarını model almalarından ve aldıkları modelleri içselleştirmelerinden kaynaklanmaktadır (Kandır ve Alpan, 2008). Bu kapsamda insanlarda doğuştan getirildiği ifade edilen öfke ve öfkenin kontrolünün istendik yönde yapılandırılması gerekmektedir. Öfke kişinin herhangi bir engellenme durumunda ortaya çıkarak karşıdaki kişi ya da objeye karşı saldırganca davranışlarda bulunmasıyla sonuçlanan bir duygu durumu olarak tarif edilebilir (DeMirando- Trinco, Santos ve Barbosa, 2017; Özmen, 2006). Öfke insanlarda farklı şekillerde ortaya çıkabilmektedir (Batıgün, 2004; Erkek, Özgür ve Babacan- Gümüş, 2006). İnsanlarda öfke, öfkenin içe vurulmas1, öfkenin dışa vurulması ve öfkenin kontrol edilmesi biçiminde kendini göstermektedir (Bostanc1, Çoban, Tekin ve Özen, 2006; Lerner, 2007; Starner ve Peters, 2004; Sung, Puskar ve Sereika, 2006; Tambağ ve 
Öz, 2005). Bu öfke çeşitlerinden öfke dışa vurumunda, kişi yaşamış olduğu öfkeyi gerek sözel, gerekse davranışsal yollarla dışarıya yöneltmektedir. Öfke içe vurumunda ise birey öfkelendiği şey ya da nesneye öfkesini yansıtmadan kendi içine dönmektedir. Öfke kontrolü ise kişinin engellenme durumunda sakin kalabilmesini, duygu ve davranışlarını düzenleyebilmesini gerektiren bir yetenektir (Starner ve Peters, 2004).

Özellikle ergenlik döneminde ergenin bir taraftan bireyselleşme çabaları, diğer taraftan ebeveynleri başta olmak üzere öğretmenlerinin, iletişim ve etkileşim içinde bulunduğu kişilerle yaşanan olumsuzluklar, ergenin öfkelenmesine neden olabilmektedir (Özmen, Özmen, Çetinkaya ve Akil, 2016). Oldukça normal olarak kabul edilen bu öfkenin ergen tarafindan kontrol edilememesi sonucunda istenmeyen ve yıkıc1 sonuçlar da ortaya çıkabilmektedir (Albayrak ve Kutlu, 2009; DeMirando- Trinco vd., 2017). Özellikle eğitim sisteminde çocuklarla birlikte olan ergenlerin, öfkelerini kontrol edebilmeleri, çocukların etrafındaki yetişkinlerin davranışlarını rol-model olarak aldıkları göz önünde bulundurulduğunda hayati öneme sahiptir. Çocuklarla bir arada olan ergenlerin bir grubu olan kız meslek lisesi çocuk gelişimi bölümü öğrencileri, eğitimleri devam ederken stajlara çıkmakta ve bu stajlarda özellikle okul öncesi dönem çocuklarıla bir arada bulunmaktadır (http://mevzuat.meb.gov.tr/html/24804_0html.) ki bir arada bulundukları dönem çocuklarının özellikleri göz önüne alındığında öfkelerini kontrol altına almaları beklenmekte ve istenmektedir.

Okul öncesi dönem insan hayatında en önemli olan dönemlerden biri olması bakımından kritik öneme sahiptir. Çocuk bu dönemde alacağı her türlü bilgi ve davranışla hayatını şekillendirebilecektir (Fujisawa, Todo ve Ando, 2017; Karaca, Gündüz ve Aral, 2011). Bu şekillendirmede pek çok etken söz konusu olsa da, çocukla iletişim ve etkileşim içinde bulunan kişiler, çocuğun hayatına direk müdahalede bulunabilen etkili bir güçtür. Çocukların bu kişilerle olan etkileşimleri tüm gelişim alanlarını etkileyebilmektedir (Bedge ve Özyürek, 2016; Tayler, 2015; Ulutaş ve Macun, 2016).

Öfkenin tam karşı kutbunda yer alan ve doğuştan getirildiği ifade edilen sevme, insanlar arasındaki en önemli duygulardan bir diğeridir. Toplumun huzurlu inşasında birbirlerini seven, birbirlerine anlayışla yaklaşan insanların varllğı yadsınamaz (Semerci, 2011). Çocukta tüm diğer duyguları etrafindaki kişilerin davranışlarını içselleştirerek öğrendiği gibi sevgiyi de yaşayarak öğrenecektir (Tezel- Şahin ve Özyürek, 2008). Aynı zamanda karşlıksız olarak sevildiğini bilen çocuklar potansiyellerini daha iyi geliştirebilmekte, potansiyellerini daha iyi geliştirebilmeleri ise onların gelişim alanlarının desteklenmesine yardımcı olabilmektedir (Duyan ve Gelbal, 2008; Whitney, 2016). Bu açıdan ele alındığında çocuklarla iletişim ve etkileşim içinde olan kız meslek lisesi öğrencilerinin de çocuk sevmelerinin ve davranışlarının buna göre yönlendirilmelerinin önemli olduğu düşünülmektedir. Yapılan araştırmalar da bu düşünceyi desteklemekte, çocuklara sevgiyle yaklaşıldığında disiplin sorunlarının daha az görüldüğü (Ergün ve Özdaş, 1999), çocukların sosyal davranışsal açıdan istendik yönde özellikler gösterdiği sonucuna ulaşılmıştır (Cottone, Mashburn ve Rimm-Kaufman, 2008; Downing, Ryndok ve Clare, 2000; Myers, 2009; Şahin ve Anlıak, 2008). Tüm bu bilgilerden hareketle araştırmada kız meslek lisesi çocuk gelişimi bölümü öğrencilerinin bazı sosyodemografik değisskenlere göre sürekli öfke- öfke ifade tarzı ve çocuk 
sevme ölçekleri arasında anlamlı farklılık olup olmadığını belirlemek, sürekli öfke- öfke ifade tarzı ile çocuk sevme puanları arasındaki ilişkiyi saptamak amaçlanmıştır. Bu amaç altında araştırmada aşağıdaki sorulara cevap aranmıştır.

1. Kız meslek lisesi çocuk gelişimi bölümü öğrencilerinin yaş, sınıf, kardeş sayısı, doğum sırası, anne-baba öğrenim durumu, üniversiteye gitme tercihi ve iletişim eğitimi alma durumu ile sürekli öfke- öfke ifade tarzları arasında anlamlı farklılık var mıdır?

2. Kız meslek lisesi çocuk gelişimi bölümü öğrencilerinin yaş, sınıf, kardeş sayısı, doğum sırası, anne-baba öğrenim durumu, üniversiteye gitme tercihi, iletişim eğitimi alma durumu ile çocuk sevme ölçeği arasında anlamlı farklılık var mıdır?

3. Kız meslek lisesi çocuk gelişimi bölümü öğrencilerinin sürekli öfke- öfke ifade tarzı ile çocuk sevme ölçeğinden aldıkları puanlar arasında ilişki var mıdır?

\section{Yöntem}

Bu bölümde, araştırmanın modeli, çalışma grubu, veri toplama araçları ve verilerin analizine yönelik bilgiler sunulmaktadır.

\section{Araştırmanın Modeli}

Araştırmada nicel araştırma yöntemlerinden tarama modeli kullanılmışıtır. Büyüköztürk, Kıllıç-Çakmak, Akgün, Karadeniz ve Demirel (2016) tarama modelini, "Bir konuya ya da olaya ilişkin katulmonclarn genellikle diğer araştırmaculara göre daha büyü̈ örneklemler üzerinde yapılan araştırmalara tarama araștırmalar” şeklinde tanımlamaktadır. Araştırmada kız meslek lisesi çocuk gelişimi bölümü öğrencilerinin bazı sosyodemografik değişkenlere göre sürekli öfke- öfke ifade tarzları ile çocuk sevme arasında anlamlı farklılık olup olmadığını belirlemek, sürekli öfke- öfke ifade tarzı ile çocuk sevme arasında ilişki olup olmadığını saptamak amacıyla tarama modeli kullanılmıştır.

\section{Çalışma Grubu-Evren Örneklem}

Araştırma Bingöl İl Milli Eğitim Müdürlüğü'ne bağlı olan ve Merkez ve Genç ilçelerinde bulunan Kız Meslek Lisesi Çocuk Gelişimi Bölümünde 2017- 2018 güz döneminde eğitim gören öğrencilerle gerçekleştirilmiştir. Çalışmada örneklem seçimine gidilmemiş, çalışmaya gönüllü olarak katılmayı kabul eden tüm öğrencilerle çalışılmış ve bu kapsamda 293 öğrenciye ulaşılmıştır. Araştırmaya dahil edilen öğrencilerin \%54,6’s1 16 yaş ve üzerindeyken, \%42,3’ü 15 yaş, \%3,1’i 14 yaşındadır. Öğrencilerin \%42’si dördüncü sınıf, \%26,3’ü birinci sınıf, \%21,5’i üçüncü sınıf, \%10,3’ü ikinci sınıf öğrencisidir. Öğrencilerin \%34,5’i ilk, \%34,1'i son, \%31,4'ü ise ortanca sırada doğmuşlardır. Öğrencilerin annelerinin \%41,3’ünün okuryazar- ilkokul, \%36,3'ünün lise, \%14'ünün ortaokul, \%8,2'sinin üniversite mezunu olduğu, babalarının \%47,1'inin okuryazar- ilkokul, \%23,5'inin ortaokul, \%21,5'inin lise, \%7,8'inin üniversite mezunu olduğu belirlenmiştir. Öğrencilerin \%66,6's1 üniversiteye gitmek istediğini, \%33,4’ü üniversiteye gitmek istemediğini, \%75,1’i iletişim dersi almadığını, \%24,9’u iletişim dersi aldığını ifade etmiştir. 


\section{Veri Toplama Araçları}

Araştırmada Kız Meslek Lisesi Çocuk Gelişimi Bölümü öğrencilerinin sosyodemografik özelliklerini belirlemek için "Genel Bilgi Formu", öğrencilerin çocuk sevme durumlarını belirlemek için "Barnett Çocuk Sevme Ölçeği ve öfke tarzlarını belirlemek için "Sürekli Öfke- Öfke İfade Tarzı Ölçeği” kullanılmışır.

\section{Genel Bilgi Formu}

Öğrencilerin yaş, eğitim gördüğü sınıf, kardeş sayısı, doğum sırası, anne-baba öğrenim durumu, üniversite ile ilgili görüşlerini ve iletişim eğitimi alıp almadıklarını belirlemek için araştırmacılar tarafindan oluşturulan formdur.

\section{Barnett Çocuk Sevme Ölçĕgi}

Barnett ve Sinisi (1990) tarafindan geliştirilmiş Türkçeye uyarlaması Duyan ve Gelbal (2008) tarafindan yapılmıştır. Tek boyuttan oluşan ve toplam puan alınan ölçek yedili likert tipinde düzenlenmiştir. Ölçekteki maddelerin dördü olumsuz, onu ise olumludur. Türkçeye uyarlama çalş̧ması sırasında .85 olarak bulunan Cronbach Alfa katsayısı, araştırmada .87 olarak bulunmuştur.

\section{Sürekli Öfke- Öfke Ífade Tarzı Ölçeği}

Spielberger vd. (1983) tarafindan geliştirilmiş ve Türkçeye uyarlaması Özer (1994) tarafindan yapılmıştır. 34 madde ve dörtlü likert tipinden oluşan ölçeğin ilk on maddesi sürekli öfkeyi, geriye kalan 24 madde ise öfke ifade tarzını oluşturmaktadır. Öfke ifade tarzı ölçeği, öfke içe, öfke dışa ve öfke kontrol olmak üzere üç alt boyuttan oluşmaktadır. Bu alt boyutlardan sürekli öfke, kişin kendini nasıl hissettiğini, öfke içe, öfkeyi içinde yaşamasını, öfke dışa, öfkenin dışarıdaki nesne ya da insanlara yönlendirilmesini ve öfke kontrolü ise kişinin öfkesini kontrol altında tutabilmesini ifade etmektedir. Türkçeye uyarlama çalş̧ması sırasında Cronbach Alfa katsayıları öfke kontrolü için .84, öfke dışa vurumu için .78, öfke içe vurumu için .62, sürekli öfke için .80 olarak bulunmuştur (Özer, 1994). Araştırma kapsamında yapılan güvenirlik analizi sonucunda Cronbach Alfa değerleri Sürekli öfke ölçeği için .87; öfke içe vurumu alt boyutu için .70 , öfke dışa vurumu alt boyutu için .80 ve öfke kontrolü alt boyutu için .74 olarak bulunmuştur.

\section{Verilerin Analizi}

Verilerin analizinde SPSS 15 paket programı kullanılmıştır. Katılımcıların vermiş oldukları cevapların normal dağılım gösterip göstermediğini belirlemek için Kurtosis ve Skewness değerleri ile KolmogorovSmirnov test sonuçlarına bakılmıştır. Yapılan istatistiksel analiz sonucunda dağılımın normal dağılım göstermediği belirlenmiş ve nonparametrik testler kullanılmıştır. Çocuk sevme ölçeği ile sürekli öfke- öfke ifade tarzı ölçekleri ile sosyodemografik değişkenler arasında anlamlı farklılık olup olmadığını belirlemek için Kruskal Wallis ve Mann Whitney U testi, anlamlı farklılığın hangi alt gruplardan kaynaklandığını belirlemek için Mann Whitney U testi; çocuk sevme ölçeği ile sürekli öfke- öfke ifade tarzı ölçekleri arasında anlamlı ilişkinin olup olmadığını belirlemek için Spearman Korelasyon katsayısı kullanılmıştır. 


\section{Bulgular ve Tartışma}

Kız Meslek Lisesi Çocuk Gelişimi Bölümü öğrencilerinin sürekli öfke- öfke ifade tarzları ile çocuk sevme düzeylerini bazı sosyodemografik değişkenlere göre anlamlı farklılık gösterip göstermediğini belirlemek ve sürekli öfke- öfke ifade tarzı ile çocuk sevme ölçekleri arasında anlamlı ilişkinin olup olmadığını saptamak amacıyla yapılan araştırma bulgularına aşağıda yer verilmiştir.

Tablo 1. Kız meslek lisesi çocuk gelişimi bölümü öğrencilerinin sınıf değişkenine göre Sürekli Öfke- Öfke İfade Tarzı alt boyutları ile Çocuk Sevme Ölçeğine ait ortalamalar ve Kruskal Wallis testi sonuçları

\begin{tabular}{|c|c|c|c|c|c|c|c|}
\hline Ölçekler & $\begin{array}{l}\text { Sinıf } \\
\text { düzeyi }\end{array}$ & $\mathbf{n}$ & $\begin{array}{l}\text { Siralar } \\
\text { ortalamas1 }\end{array}$ & $\mathrm{X}^{2}$ & Sd & $\mathrm{p}$ & $\begin{array}{l}\text { Anlamlı } \\
\text { fark }\end{array}$ \\
\hline Sürekli & $1^{1}$ & 77 & 144,84 & & & & \\
\hline \multirow[t]{3}{*}{ Öfke } & $2^{2}$ & 30 & 122,80 & & & & \\
\hline & $3^{3}$ & 63 & 149,67 & 8,21 & 4 & .08 & \\
\hline & $4^{4}$ & 123 & 150,18 & & & & \\
\hline \multicolumn{8}{|l|}{ Öfke İfade } \\
\hline \multicolumn{8}{|l|}{$\begin{array}{l}\text { Tarz1 } \\
\text { Ölceği }\end{array}$} \\
\hline \multirow[t]{4}{*}{ Öfke İçe } & $1^{1}$ & 77 & 131,82 & & & & \\
\hline & $2^{2}$ & 30 & 151,66 & 5 & 4 & .29 & \\
\hline & $3^{3}$ & 63 & 150,80 & & & & \\
\hline & $4^{4}$ & 123 & 152,18 & & & & \\
\hline \multirow[t]{4}{*}{ Öfke Dışa } & $1^{1}$ & 77 & 158,36 & & & & \\
\hline & $2^{2}$ & 30 & 115,64 & 10.06 & 4 & .04 & \\
\hline & $3^{3}$ & 63 & 147,76 & & & & \\
\hline & $4^{4}$ & 123 & 144,53 & & & & \\
\hline Öfke & $1^{1}$ & 77 & 118,47 & & & & \\
\hline \multirow[t]{3}{*}{ Kontrol } & $2^{2}$ & 30 & 140,50 & 25,57 & 4 & .000 & $1-4$ \\
\hline & $3^{3}$ & 63 & 140,56 & & & & \\
\hline & $4^{4}$ & 123 & 171,93 & & & & \\
\hline Çocuk & $1^{1}$ & 77 & 129,41 & & & & \\
\hline Sevme & $2^{2}$ & 30 & 143,57 & 6,45 & 4 & .17 & \\
\hline \multirow[t]{2}{*}{ Ölçeği } & $3^{3}$ & 63 & 145,25 & & & & \\
\hline & $4^{4}$ & 123 & 158,92 & & & & \\
\hline
\end{tabular}

Tablo 1'de görüldüğü gibi kız meslek lisesi çocuk gelişimi bölümü öğrencilerinin sınıfa göre öfke ifade tarzı ölçeğinin, öfke kontrol alt boyutunda anlamlı farklllığın olduğu bulunmuştur $\left(\mathrm{x}^{2}=25,57 ; \mathrm{p}<.01\right)$. Buna göre dördüncü sınıf öğrencilerinin $(X=114,70)$, birinci sınıf öğrencilerine göre $(X=77,82)$ öfkelerini daha iyi kontrol edebildikleri bulunmuştur. Bu durumu öğrencilerin sınıf düzeyi arttıkça öğrenim gördükleri alanda bilinç ve farkındalık kazanarak özellikle çocuklarla birlikte oldukları anda davranışlarını kontrol edebilmelerinin anlamını daha iyi özümseme çabalarılla açıklamak mümkündür. Çünkü almış oldukları dersler arasında yer alan çocuk gelişimi derslerinin üst sınıflarda daha da yoğunlaşmış olmaları ve birinci sınıftan itibaren olan bilgi birikimleri (Çam, 2016), ergenlikte doğal bir duygu olarak ifade edilen öfke duygularını daha iyi kontrol edebilmelerine (Adana ve Arslantaş, 2011) yardımcı olacağ1 düşünülmektedir. Nitekim yapılan araştırmalarda sınıf seviyesi yükseldikçe öğretmen adaylarının öfkelerini daha iyi kontrol ettikleri bulunmuştur (Ören ve Türkoğlu, 2011). Sınıf değişkenine göre sürekli öfke ölçeği ile ( $\left.x^{2}=.08 ; \mathrm{p}>.01\right)$ ve çocuk sevme ölçeği arasında $\left(x^{2}=6,45 ; \mathrm{p}>.01\right)$ anlamlı farklılık bulunamamıştır. 
Tablo 2. Kız meslek lisesi çocuk gelişimi bölümü öğrencilerinin kardeş sayısına göre Sürekli Öfke- Öfke İfade Tarzı Ölçeği ve Çocuk Sevme Ölçeğine ait ortalamalar ve Kruskal Wallis testi sonuçlar1

\begin{tabular}{|c|c|c|c|c|c|c|c|}
\hline Ölçekler & $\begin{array}{l}\text { Kardeş } \\
\text { say1s1 }\end{array}$ & $n$ & $\begin{array}{l}\text { Siralar } \\
\text { ortalamas1 }\end{array}$ & $\mathbf{X}^{2}$ & Sd & $\mathrm{p}$ & $\begin{array}{l}\text { Anlaml1 } \\
\text { fark }\end{array}$ \\
\hline Sürekli & $\mathrm{Tek}^{1}$ & 23 & 111,20 & & & & \\
\hline \multirow[t]{2}{*}{ Öfke } & 2 kardeş ${ }^{2}$ & 120 & 133,01 & 13,24 & 2 & .001 & $2-3$ \\
\hline & $\begin{array}{l}3 \text { ve üstü } \\
\text { kardeş }^{3}\end{array}$ & 150 & 163,68 & & & & \\
\hline \multirow{2}{*}{\multicolumn{8}{|c|}{$\begin{array}{l}\text { Öfke Iffade } \\
\text { Tarzı } \\
\text { Ölçeği }\end{array}$}} \\
\hline & & & & & & & \\
\hline \multirow[t]{3}{*}{ Öfke İçe } & Tek $^{1}$ & 23 & 125 & & & & \\
\hline & 2 kardeş ${ }^{2}$ & 120 & 139,06 & 4,61 & 2 & .1 & \\
\hline & $\begin{array}{l}3 \text { ve üzeri } \\
\text { kardeş3 }\end{array}$ & 150 & 156,73 & & & & \\
\hline \multirow[t]{3}{*}{ Öfke Dışa } & $\mathrm{Tek}^{1}$ & 23 & 91,35 & & & & \\
\hline & 2 kardeş ${ }^{2}$ & 120 & 138,66 & 16,01 & 2 & .000 & $1-3$ \\
\hline & $\begin{array}{l}3 \text { ve üzeri } \\
\text { kardeş }^{3}\end{array}$ & 150 & 162,21 & & & & \\
\hline Öfke & $\mathrm{Tek}^{1}$ & 23 & 131,50 & & & & \\
\hline \multirow[t]{2}{*}{ Kontrol } & 2 Kardeş $^{2}$ & 120 & 151,99 & 18,04 & 2 & .000 & $2-3$ \\
\hline & $\begin{array}{l}3 \text { ve üzeri } \\
\text { kardeş }^{3}\end{array}$ & 150 & 145,94 & & & & \\
\hline Çocuk & Tek $^{1}$ & 23 & 129,03 & & & & \\
\hline Sevme & 2 kardeş ${ }^{2}$ & 120 & 140,06 & 1,10 & 2 & .58 & \\
\hline Ölçeği & $\begin{array}{l}3 \text { ve üzeri } \\
\text { kardes }^{3}\end{array}$ & 150 & 145,72 & & & & \\
\hline
\end{tabular}

Tablo 2'de görüldüğü gibi kız meslek lisesi çocuk gelişimi bölümü öğrencilerinin kardeş sayısına göre sürekli öfke ölçeği $\left(x^{2}=13,24 ; \mathrm{p}<.01\right)$, öfke ifade tarz1 ölçeğinin alt boyutlarından öfke dışa $\left(x^{2}=16,01\right.$; $\mathrm{p}<.01)$ ve öfke kontrolü $\left(\mathrm{x}^{2}=18,04 ; \mathrm{p}<.01\right)$ arasında anlamlı farkl1l1k olduğu bulunmuştur. Söz konusu farklıllk sürekli öfke ölçeğinde üç ve üzeri kardeşe sahip olan öğrenciler lehine gerçekleşmiştir. Üç ve üzerinde kardeşe sahip olan öğrencilerin sıra ortalaması $(X=163,68)$, iki kardeşe sahip olan öğrencilerin sıra ortalamasından $(X=133,01)$ yüksektir. Öfke ifade tarzı ölçeği alt boyutlarından öfke dışa alt boyutunda anlamlı farklılık üç ve üzeri kardeşe sahip olan öğrenciler, öfke kontrol alt boyutunda ise iki kardeşe sahip olan öğrenciler lehine gerçekleşmiştir. Öfke dışa alt boyutunda üç ve üzeri kardeşe sahip olan öğrencilerin sıra ortalaması $(X=162,21)$, tek çocuk olan öğrencilerin sıra ortalamasından $(X=91,35)$; öfke kontrol alt boyutunda ise iki kardeşe sahip olan öğrencilerin sıra ortalaması (X=151,99), üç ve üzeri kardeşe sahip olan öğrencilerin sıra ortalamasından $(X=145,94)$ yüksek olarak bulunmuştur. Bu durum kardeş sayısı arttıkça öfke düzeylerinin arttığını, kardeş sayısı azaldığında ise çocukların öfkelerini daha iyi kontrol edebildiklerini göstermektedir. Çocuk için kardeş önemli bir faktördür. Çocuğun kişilik gelişiminde, sosyal anlamda olgunlaşmasında kardeş önemli olmakla birlikte, kardeş sayısı arttıkça ebeveynlerin ilgi ve sevgisi bölündüğü için çocuklarda öfke duygusunun artıs gösterdiği de bilinmektedir (Song ve Valling, 2018). Ancak bu duruma koşut olarak, kardeş sayısının azalması hem eşit oranda ebeveynin ilgi ve sevgisinin paylaşılmasını, hem çatışma çözme becerilerini daha iyi yapılandırmayı da getireceği için öfke kontrolü artmaktadır (Öz-Soysal, 2016). Yapılan araştırmalarda kardeş sayısı arttıkça çocuklarda agresif davranışlar ve öfkenin arttığını gösterir yönde olurken (Chad, Simpson ve Ellis, 2016; 
Dereli- İman, 2015; Gökçearslan- Çifci, 2009; Kumador, Ofosu ve Mohama, 2018), kardeş sayısının bir ya da iki olması sonucunda çocukların yaşam doyumlarının daha iyi düzeyde olduğu ve buna paralel olarak da öfkelerini daha iyi kontrol altına alabildiklerini göstermiştir (Acar, Demir, Görmez ve Keser, 2015; Çetinkaya, Nur, Ayvaz, Özdemir ve Kavakçı, 2009; Gültekin-Akduman ve Baran, 2011; Öz-Soysal, 2016; Sawai ve Kato, 2017; Volkom ve Beaudoin, 2016). Kız meslek lisesi çocuk gelişimi bölümü öğrencilerinin kardeş sayısına göre çocuk sevme ölçeği arasında anlamlı farklılık bulunamamıştır $\left(\mathrm{x}^{2}=1,10 ; \mathrm{p}>.01\right)$.

Tablo 3. Kız meslek lisesi çocuk gelişimi bölümü öğrencilerinin anne öğrenimine göre Sürekli Öfke- Öfke İfade Tarzı ve Çocuk Sevme Ölçeğine ait ortalamalar ve Kruskal Wallis testi sonuçlar1

\begin{tabular}{|c|c|c|c|c|c|c|c|}
\hline Ölçekler & $\begin{array}{l}\text { Anne } \\
\text { eğitim }\end{array}$ & $\mathrm{n}$ & $\begin{array}{l}\text { Siralar } \\
\text { ortalamas1 }\end{array}$ & $\mathrm{X}^{2}$ & Sd & $\mathrm{p}$ & $\begin{array}{l}\text { Anlamlı } \\
\text { fark }\end{array}$ \\
\hline \multirow[t]{4}{*}{$\begin{array}{l}\text { Sürekli } \\
\text { öfke }\end{array}$} & $\begin{array}{l}\text { Okuryazar- } \\
\text { ilkokul }^{1}\end{array}$ & 121 & 152,50 & & & & \\
\hline & Ortaokul ${ }^{2}$ & 41 & 133,06 & 4,84 & 3 & .18 & \\
\hline & Lise $^{3}$ & 107 & 152,54 & & & & \\
\hline & Üniversite $^{4}$ & 24 & 118,35 & & & & \\
\hline \multirow{2}{*}{\multicolumn{8}{|c|}{$\begin{array}{l}\text { Öfke İfade } \\
\text { Tarzı } \\
\text { Ölçeği }\end{array}$}} \\
\hline & & & & & & & \\
\hline \multirow[t]{4}{*}{ Öfke İçe } & $\begin{array}{l}\text { Okuryazar- } \\
\text { ilkokul }^{1}\end{array}$ & 121 & 144,02 & 1,34 & 3 & .72 & \\
\hline & Ortaokul ${ }^{2}$ & 41 & 147,23 & & & & \\
\hline & Lise $^{3}$ & 107 & 152,27 & & & & \\
\hline & Üniversite $^{4}$ & 24 & 133,67 & & & & \\
\hline \multirow[t]{4}{*}{ Öfke Dışa } & $\begin{array}{l}\text { Okuryazar- } \\
\text { ilkokul }^{1}\end{array}$ & 121 & 153,75 & & & & \\
\hline & Ortaokul $^{2}$ & 41 & 147,46 & 3,05 & 3 & .38 & \\
\hline & Lise $^{3}$ & 107 & 144,95 & & & & \\
\hline & Üniversite $^{4}$ & 24 & 121,33 & & & & \\
\hline \multirow[t]{4}{*}{$\begin{array}{l}\text { Öfke } \\
\text { Kontrol }\end{array}$} & $\begin{array}{l}\text { Okuryazar- } \\
\text { ilkokul }^{1}\end{array}$ & 41 & 137,02 & & & & \\
\hline & Ortaokul $^{2}$ & 107 & 116,91 & & & & \\
\hline & Lise $^{3}$ & 24 & 162,04 & 14,31 & 3 & .003 & $2-3$ \\
\hline & Üniversite ${ }^{4}$ & 41 & 181,67 & & & & $2-4$ \\
\hline \multirow{4}{*}{$\begin{array}{l}\text { Çocuk } \\
\text { Sevme }\end{array}$} & $\begin{array}{l}\text { Okuryazar- } \\
\text { ilkokul }^{1}\end{array}$ & 121 & 143,78 & & & & \\
\hline & Ortaokul 2 & 41 & 135,27 & & & & \\
\hline & Lise $^{3}$ & 107 & 154,73 & 1,86 & 3 & .60 & \\
\hline & Üniversite $^{4}$ & 24 & 148,81 & & & & \\
\hline
\end{tabular}

Tablo 3'de görüldüğü gibi kız meslek lisesi çocuk gelişimi bölümü öğrencilerinin anne öğrenimine göre öfke ifade tarzı ölçeği alt boyutlanından öfke kontrol alt boyutunda anlamlı farklılık olduğu görülmektedir $\left(\mathrm{x}^{2}=14,31 ; \mathrm{p}<.01\right)$. Annesi lise mezunu olan öğrencilerin sıra ortalaması $(\mathrm{X}=162,04)$, annesi ortaokul mezunu olan öğrencilerin sıra ortalamasına göre $(X=116,91)$ ve annesi üniversite mezunu olan öğrencilerin sıra ortalaması $(X=181,67)$, annesi ortaokul mezunu olan öğrencilerin sıra ortalamasına göre $(X=116,91)$ yüksek bulunmuştur. Aile öfke yaşantılarının oluşmasında, özdeşim kurmada, model olmada önemli bir faktördür. Eğitim düzeyi, anne-baba tutumları, aile içi dinamikler ve çocuk yetiştirme tutumları, çocukların öfke düzeylerini ve öfke kontrol becerilerini etkilemektedir (Acar vd., 2015). 
Araştırma sonucunda annenin öğrenim düzeyi yükseldikçe çocukların öfkelerini daha iyi kontrol ettikleri görülmüş̧ür. Bu durum annenin eğitim seviyesinin yükselmesi sonucunda çocuklarıyla daha iyi iletişim kurabilmesiyle, çocuklarına bu yönde bir eğitim vermesiyle açıklanabilir (Alisinanoğlu, 2003; Aydemir ve Aksoy, 2010; Gültekin-Akduman ve Baran, 2011). Yapılan araştırmalarda da anne eğitim düzeyinin yükselmesiyle öfke kontrolü arasında pozitif bir ilişkinin olduğu bulunmuştur (Akdeniz, Demirci, Sekban ve Yurtsever, 2017; Kiraz, 2016). Öğrencilerin anne öğrenim durumuna göre sürekli öfke $\left(x^{2}=4,84\right.$; p>.01) ve çocuk sevme $\left(x^{2}=1,86 ; \mathrm{p}>.01\right)$ ölçekleri arasında anlamlı farkllık bulunmamışır.

Tablo 4. Kız meslek lisesi çocuk gelişimi bölümü öğrencilerinin üniversiteye gitme tercihlerine göre Sürekli Öfke- Öfke İfade Tarzı ve Çocuk Sevme Ölçeklerine ait ortalamalar ve Mann Whitney U testi sonuçları

\begin{tabular}{|c|c|c|c|c|c|c|}
\hline Ölçekler & $\begin{array}{l}\text { Üniversiteye } \\
\text { gitme } \\
\text { tercihi }\end{array}$ & $\mathrm{n}$ & $\begin{array}{l}\text { Siralar } \\
\text { ortalamas1 }\end{array}$ & $\begin{array}{l}\text { Siralar } \\
\text { toplam1 }\end{array}$ & $\mathbf{U}$ & $\mathrm{p}$ \\
\hline Sürekli Öfke & Evet & 195 & 136,53 & 26623 & 75,13 & .003 \\
\hline $\begin{array}{l}\text { Öfke İfade } \\
\text { Tarz1 }\end{array}$ & Hayır & 98 & 167,84 & 16448 & & \\
\hline Öfke İçe & $\begin{array}{l}\text { Evet } \\
\text { Hayır }\end{array}$ & $\begin{array}{l}195 \\
98\end{array}$ & $\begin{array}{l}137,66 \\
165,59\end{array}$ & $\begin{array}{l}26843,50 \\
16227,50\end{array}$ & 7733,50 & .01 \\
\hline Öfke Dışa & $\begin{array}{l}\text { Evet } \\
\text { Haylr }\end{array}$ & $\begin{array}{l}195 \\
98\end{array}$ & $\begin{array}{l}142,82 \\
155,32\end{array}$ & $\begin{array}{l}27850 \\
15221\end{array}$ & 8740 & .23 \\
\hline Öfke Kontrol & $\begin{array}{l}\text { Evet } \\
\text { Haylr }\end{array}$ & $\begin{array}{l}195 \\
98\end{array}$ & $\begin{array}{l}147,30 \\
146,40\end{array}$ & $\begin{array}{l}28724 \\
14347\end{array}$ & 9496 & .93 \\
\hline Çocuk Sevme & $\begin{array}{l}\text { Evet } \\
\text { Haylr }\end{array}$ & $\begin{array}{l}195 \\
98 \\
\end{array}$ & $\begin{array}{l}153,74 \\
133,59 \\
\end{array}$ & $\begin{array}{l}29979 \\
13092 \\
\end{array}$ & 8241 & .05 \\
\hline
\end{tabular}

Tablo 4'e göre kız meslek lisesi çocuk gelişimi bölümü öğrencilerinin üniversiteye gitme tercihlerine göre sürekli öfke ölçeği arasında anlamlı farklılık bulunmuştur $(\mathrm{U}=75,13 ; \mathrm{p}<.01)$. Üniversiteye gitmek istemeyen öğrencilerin sürekli öfke sıra ortalamaları $(X=167,84)$, üniversiteye gitmek isteyen öğrencilerin sıra ortalamasından $(X=136,53)$ yüksek bulunmuştur. Üniversiteye gitmek bir tercih nedeni olarak görülse de, bu tercihi etkileyebilecek faktörler bulunmaktadır. Bu faktörlerden biri sosyoekonomik durum ve ebeveynlerin eğitim düzeyi iken, bir diğeri ise ergenin ne olacağına yönelik karar verebilme becerisidir. Anne ve babaların eğitim düzeyinin düşük olması, sosyoekonomik anlamda da dar boğazı getirmekte ve bunun sonucunda da ergen öfkelenebilmektedir. Maddi imkansızlıklarla paralel olarak üniversiteye gitmek de istemeyebilmekte bu da öfke duygusunun yükselmesine neden olabilmektedir (Aral vd., 2016; Özer ve Çolak, 2015). Aynı zamanda ergenlik döneminin bitmesiyle başlayan üniversiteye gitme tercihi, ergenin kim olduğuna yönelik soruları cevaplamasını da gerektirir. Kim olduğuna yönelik soruları cevaplayabilen, bir başka ifadeyle ergenlik dönemini sorunsuz atlatan kişilerin öfke düzeyleri düşük ve öfke kontrolleri daha yüksektir (Fazlıoğlu, 2017). Bu bakış açısının da üniversiteye gitmek istemeyen ergenlerin öfke düzeylerinin yüksekliğini açılladığı düşünülmektedir. Öğrencilerin üniversiteye gitme tercihlerine göre öfke ifade tarzı alt boyutlarından öfke içe (U=7733,50; p>.01), öfke dişa ( $U=8740 ;$ p>.01),öfke kontrol (U=9496; p>.01) ve çocuk sevme ölçeği ( $U=8241$; p >.01) arasında anlamlı farklılık bulunmamıştır. 
Tablo 5. Kız meslek lisesi çocuk gelişimi bölümü öğrencilerinin Sürekli Öfke- Öfke İfade Tarzı Ölçeği ve Çocuk Sevme Ölçeği arasındaki Korelasyon analizi sonuçları

\begin{tabular}{ll}
\hline & Barnett Çocuk Sevme Ölçeği \\
\hline Sürekli Öfke & $\mathrm{r}=.15 ; \mathrm{p}=.01$ \\
Öfke İçe & $\mathrm{r}=.16 ; \mathrm{p}=.01$ \\
Öfke Dişa & $\mathrm{r}=.14 ; \mathrm{p}=.01$ \\
Öfke Kontrol & $\mathrm{r}=.26 ; \mathrm{p}=.000$ \\
\hline
\end{tabular}

Tablo 5'de görüldüğü gibi kız meslek lisesi çocuk gelişimi bölümü öğrencilerinin öfke kontrol alt boyutunda aldıkları puanlarla Barnett Çocuk Sevme Ölçeğinden aldıkları puanlar arasında orta derecede pozitif yönde anlamlı bir ilişki bulunmuştur $(\mathrm{r}=.26 ; \mathrm{p}<.01)$. Öfke kontrolü arttıkça, çocuk sevme de artmaktadır. Bu durumu öfke ile sevmenin birbirine karşıt duygular olmasıyla açıklamak mümkündür. Öfke, insanlar arası ilişkilerde istenmeyen bir duygudur ve beraberinde nefreti getirmektedir. $\mathrm{Bu}$ duygunun tam karşı kutbunda ise sevme ve sevgi yer almaktadır (Ilgar, 2013). Yapılan araştırmalarda da öfke duygusunun daha çok saldırganlığa yol açacağını, öfkenin kontrolünün ise daha istendik davranışlarla sonuçlanacağı üzerinde durmaktadır (Albayrak ve Kutlu, 2009; Pickens, 2009; Şahin, Batıgün ve Koç, 2011; Yuu, 2010). Özellikle öğretmenlik mesleğinde öfkeli davranışların her zaman olumsuz sonuçlar doğuracağı da yapılmış araştırmalarda sıklıkla vurgulanan bir diğer önemli konudur (Babaoğlan, 2007; Oktay, 2007). Öğretmen adayları içinde bu durum oldukça önemlidir. Çünkü mezun olduktan sonra başarılı olabilmenin ön şartları okul döneminde atılmaktadır (Yöndem ve Bıçak, 2008). Ayrıca öğretmen adaylarının özellikle lise döneminde olanların, ergenlik döneminde bulunmaları ve dolasıyla öfkelerini kontrol edebilmeleri (Adana ve Arslantaş, 2011), öğrencilere beraberinde akademik başarıyı da getirebilir. Tüm bu durumlar göz önüne alındığında ise öfke kontrolünün artmasının çocuk sevme durumunu da beraberinde getireceği düşünülmektedir.

Araştırma sonucunda kız meslek lisesi çocuk gelişimi bölümü öğrencilerinin yaş, doğum sırası, baba öğrenim durumu, iletişim dersi alma durumlarına göre sürekli öfke- öfke ifade tarzı ve çocuk sevme ölçekleri arasında anlamlı farklılık bulunmamışıı (p>.01).

\section{Sonuç ve Öneriler}

Araştırma sonucunda, sınıf düzeyi arttıkça öğrencilerin öfkelerini daha iyi kontrol ettikleri, kardeş sayısı arttıkça öfke düzeyinin arttığı, iki kardeşi olan çocukların öfkelerini daha iyi kontrol edebildiği, annenin eğitim düzeyi yükseldikçe öğrencilerin öfkelerini daha iyi kontrol ettikleri, üniversiteye gitmek istemeyen öğrencilerin daha fazla öfkeli oldukları, öfke kontrolü ile çocuk sevme ölçeği arasında pozitif yönde anlamlı bir ilişkinin olduğu sonucuna ulaşılmıştır. Araştırmadan elde edilen sonuçlara dayanarak;

1. Öğrencilere birinci sınıftan itibaren verilen çocuk eğitimine yönelik bilgilerin daha etkili biçimde sunulmas1,

2. Ailede kardeşler arasındaki ilişki ve etkileşimlerin sağlıklı ve istendik yönde nasıl gerçekleştirilebileceğine yönelik okullarda rehberlik hizmetlerinin daha etkili şekilde sunulması,

3. Annelere öfke kontrolü ve çocuklarındaki öfkenin olumlu şekilde yönetilebilmesi, kardeşler arasındaki dayanışmayı nasıl arttırılabileceğine yönelik eğitimler sağlanması önerilebilir. 


\section{Kaynakça}

Acar, G., Demir, A, Görmez, D., Keser, İ. (2015). Aile ve çocuk suçluluğu ilişkisi. Hacettepe Üniversitesi Sağhlk Bilimleri Fakültesi Dergisi, 1, 651-656.

Adana, F.,Arslantaş, H. (2011). Ergenlikte öfke ve öfkenin yönetiminde okul hemşiresinin rolü. Adnan Menderes Üniversitesi Tap Fakültesi Dergisi, 12(1), 57-62.

Akdeniz, H., Demirci, D., Sekban, G., Yurtsever, Y. (2017). Üniversite öğrencilerinin öfke düzeylerin karşılaştırlması: Kocaeli üniversitesi örneği. Muş Alparaslan Üniversitesi Uluslararası Spor Bilimleri Dergisi, 1(1), 46-60.

Albayrak, B., Kutlu, Y. (2009). Ergenlerde öfke ifade tarzı ve ilişkili faktörler. Maltepe Üniversitesi Hemsirelik Bilim ve Sanat Dergisi, 2(3), 57-65.

Alisinanoğlu, F. (2003). Çocukların denetim odağı ile algıladıkları anne tutumları arasındaki ilişkinin incelenmesi. Türk Eğitim Bilimleri Dergisi, 1(1), 97-108.

Aral, N., Özdoğan-Özbal, E., Gürsoy, F., Çetin-Sultanoğlu, S., Aydos, S., Tosun, S., Karaaslan, T., Kadan, G. (2016). Poverty definitions through children's eyes. Journal of Current Researches on Health Sector, 6(1), 39-50.

Aydemir, H., Aksoy, N.D. (2010). Eğitim fakültesi öğrencilerin demokratik tutumlarının bazı değişkenlerle ilişkisi: Malatya örneği. Eržincan Eğitim Fakültesi Dergisi, 12(1), 265-279.

Babaoğlan, E. (2007). Aday öğretmenlerde öfke. Mehmet Akif Ersoy Üniversitesi Eğitim Fakültesi Dergisi, 8(14), 30-36.

Batıgün, A.D. (2004). İntihar ile ilgili bazı değişkenler: Öfke/saldırganlık, dürtüsel davranışlar, problem çözme becerileri, yaşamı sürdürme nedenleri. Kriそ Dergisi, 12(2), 49-61.

Bedge, Z., Özyürek, A. (2016). Öğretmen ve anne-baba tutumlarının okul öncesi dönem çocuklarının problem çözme becerilerine etkisi. Amasya Üniversitesi Eğitim Fakültesi Dergisi, 5(1), 204-232.

Bostanc1, N., Çoban, Ş., Tekin, Z., Özen, A. (2006). Üniversite öğrencilerinin cinsiyete göre öfke ifade etme biçimleri. Kriz Dergisi, 14(3), 9-18.

Büyüköztürk, Ş, K1lıç-Çakmak, E., Akgün, E.Ö., Karadeniz, Ş., Demirel, F. (2016). Bilimsel araşttrma yöntemleri. Ankara: Pegem.

Chad, R.A., Simpson, C.G., Ellis, S.K. (2016). The relationship between school belonging sibling aggression and bullying involvement: Implications for students with and without disabilities. Educational Psychology, 36(8), 1462-1486.

Cottone, E.A., Mashburn, A., Rimm-Kaufman, S.E. (2008). Relationships between teachers and preschoolers who are at risk: Contribution of children's language skills, temprementally based attributes and gender. Early Education and Development, 19(4), 600-621.

Çam, S. (2016). Kız meslek lisesi öğrencilerinin çeşitli değişkenlere göre benlik kavramlarının karşılaştırılması. Psikolojik Damısma ve Rebberlik Dergisi, 1(3), 16-20. 
Çetinkaya, S., Nur, N., Ayvaz, A., Özdemir, D., Kavakçı, Ö. (2009). Sosyoekonomik durumu farklı üç ilköğretim okulu öğrencilerinde akran zorbalığının depresyon ve benlik saygısı düzeyiyle ilişkisi. Anadolu Psikiyatri Dergisi, 10, 151-158.

DeMirando- Trinco, M.E.,Santos, J.C., Barbosa, A. (2017). Experiences and needs of parents of adolescents with self-harm behaviors during hospitalization. Revista de Entermagem Referencia, IV(13), 115-124.

Dereli- İman, E. (2015). Ergenlerin çocukluk örselenme yaşantıları ile empatik eğilim, sosyal sorun çözme becerileri arasındaki ilişki. Pegem Eğitim ve Ögrretim Dergisi, 5(3), 235-256.

Downing, J.E., Ryndak, D.L., Clare, D. (2000). Para educators in inclusive classrooms: Their own perceptions. Remedial and Special Education, 21, 171-181.

Duyan, V., Gelbal, S. (2008). Barnett çocuk sevme ölçeğini Türkçeye uyarlama çalş̧ması. Eğitim ve Bilim, $33(148), 40-48$.

Erkek, N., Özgür, G., Babacan-Gümüş, A. (2006). Hipertansiyon tanısı alan hastaların sürekli öfke ve öfke ifade tarzları. CÜ Hemsirelik Yüksekokulu Dergisi, 10(2), 9-18.

Ergün, M., Özdaş, A. (1999). Okul gözlemi ve uygulama çalışmalarının öğretmen adayları üzerindeki etkisi. AKÜ Sosyal Bilimler Dergisi, 3, 115-119.

Fazlıŏlu, Y. (2017). Sosyal gelişim. N. Aral, T. Duman (ed.). Eğitim psikolojisi. Içinde (s. 154-176). Ankara: Pegem.

Fujisawa, K.K., Todo, N., Ando, J. (2017). Genetic and environment influences on the development and stability of executive functions in children of preschool age: A longitudinal study of Japanese Twins Infant and Child Development, 26, 1-27.

Gökçearslan- Çifci, E. (2009). Kapkaç suçundan hüküm giyen yetişkinlerin sosyodemografik özellikleri ve sapma davranışlar açısından incelenmesi. Aile ve Toplum, 5(18), 73-85.

Gültekin- Akduman, G., Baran, G. (2011). Suça karışan ve karşımayan 12-15 yaş grubundaki çocuklarda akran istismarının çeşitli ailesel özelliklerle ilişkisi Anatolian Journal of Psychiatry, 12, 76-83.

https://mevzuat.meb.gov.tr/html/24804 0.html. 28.04.2018.

Ilgar, L. (2013). An anaysis of the trait anger and anger expression styles of preschool teacher candidates term of some variables. International Journal Social Sciences \& Education, 3(3), 770-785.

Kandır, A., Alpan, Y. (2008). Okul öncesi dönemde sosyal duygusal gelişime anne baba davranışlarının etkisi. Aile ve Toplum, 10(4), 33-38.

Karaca, N.H., Gündüz, A., Aral, N. (2011). Okul öncesi dönem çocuklarının sosyal davranışlarının incelenmesi. Kuramsal Eğitim Bilim, 4(2), 65-76.

Kiraz, E. (2016). Ergenlerde öfke, atılganlık ve iliskili faktörler. Yüksek Lisans Tezi, Adnan Menderes Üniversitesi, Aydın.

Kumador, D., Ofosu, T.V., Mohama, S. (2018). Sibling relationships and adolescents' ineternalizing and externalizing problems. Ife Psychology $L A, 26,(1), 193-208$.

Lerner, H. (2007). Öfke dansı S. Gül (çev.). İstanbul: Varlık. 
Myers, S.S. (2009). Examining associations between effortfull control and teacher-child relationships in relation to head start children's socioemotional adjustment. Early Education and Development, 20(5), 756-774.

Oktay, A. (2007). Yaşammn sibirli yullar: Okul öncesi dönem. İstanbul: Epsilon.

Ören, N., Türkoğlu, H. (2011). Öğretmen adaylarının sürekli öfle ve öfke ifade tarzlarının çeşitli değişkenler açısından incelenmesi. Eğitimde Kuram ve Uygulama, 7(1), 160-170.

Öz-Soysal, F.S. (2016). A study on sibling relationships, life satisfaction and loneliness level of adolescents. Journal of Education and Training Studies, 4(4), 58-67.

Özer, A.K. (1994). Sürekli öfke (SL- öfke) ve öfke ifadesi tarzı (Öfke tarzı) ölçekleri ön çalısması. Türk Psikoloji Dergisi, 9(31), 26-35.

Özer, Y.E., Çolak, M. (2015). Yoksulluk, dezavantajlı grup ve suç ilişkisine yönelik bir alan araştırması: İzmir kadın sığınma evleri örneği. İktisadi ve İdari Bilimler Dergisi, 29(3), 479-491.

Özmen, A. (2006). Öfkeyle başa çıkma eğitiminin ve etkileşim grubu uygulamasının içe yönelik öfke üzerindeki etkisi. Cumburiyet Üniversitesi Sosyal Bilimler Dergisi, 30(2), 175-185.

Özmen, D., Özmen, E., Çetinkaya, A., Akil, İ.Ö. (2016). Ergenlerde sürekli öfke ve öfke ifade tarzları. Anadolu Psikiyatri Dergisi, 17, 65-73.

Pickens, J. (2009). Socioemotional programme promotes positive behavior in preschoolers. Cbild Care in Practice, 15(4), 261-278.

Sawai, M., Kato, D., (2017). Sibling relations coginition in Japanese female university students. College Student Journal, 51(4), 570-578.

Semerci, Z.B: (2011). Duygularn şifresi: Yaşama iliskilerimize ve duygularmı̨a dair. İstanbul: Alfa.

Song, J.H., Volling, B.L. (2018). Theory of mind development and early sibling relationships after the birth of a sibling: Parental discipline matters. Infant and Child Development, 27(1), 2-17.

Starner, T.M., Peters, R.M. (2004). Anger expression and blood pressure in adolescents. The Journal of School Nursing, 20(6), 335-342.

Sung, K.M., Puskar, K.R., Sereiko, S. (2006). Psikososyal faktörler ve gençlerin baş etme stratejileri bir kırsal Pennsylvania yüksekokulu. Halk Sağhl̆̆ Hemşireliği, 23(6), 523-529.

Şahin, D., Anlıak, Ş. (2008). Okul öncesi çocuklarının öğretmenleriyle kurdukları ilişkileri algılama biçimleri. Eğitim Bilimleri Uygulama, 7(14), 215-230.

Şahin, N.H., Batıgün, A.D., Koç, V. (2011). Kişilerarası tarz, kendilik algısı, öfke ve depresyon. Türk Psikiyatri Dergisi, 22(1), 17-25.

Tambağ, H., Öz, F. (2005). Aileleri ile birlikte ve yetiştirme yurtlarında yaşayan ergenlerin öfke ifade etme biçimleri. Kri‡ Dergisi, 13(1), 11-21.

Tayler, C., (2015). Learning in early childhood: Experiences, relationships and "learning to be" European Journal of Education, 50(2), 160-174.

Tezel-Şahin, F., Özyürek, A. (2008). 5-6 yaş grubu çocuğa sahip ebeveynlerin demografik özelliklerinin çocuk yetiştirme tutumlarına etkisi. Türk Eğitim Bilimleri Dergisi, 6(3), 395-414. 
Ulutaş, İ., Macun, B. (2016). Okul öncesi çocuklarının duygusal zekasını desteklemede öğretmenin rolü. Turkish Studies, 11(14), 951-964.

Volkom, V.M., Beaudoin, E. (2016). The effect of birth order and sex on perceptions of the sibling relationship among college students. College Student Journal, 50(3), 347-354.

Whitney, A.E. (2016). Partners in loving the children roles and relationships in teaching and in parenting The Educational Forum, 80, 353-364.

Yuu, K. (2010). Expressing emotions in teaching: Inducement, suppression and disclosure as caring proffesion. Educational Studies in Japon International Yearbook, 5, 63-78.

Yöndem, Z.D., Bıçak, B. (2008). Öğretmen adaylarının öfke düzeyi ve öfke tarzları. Uluslararası İnsan Bilimleri Dergisi, 5(2), 1-15. 